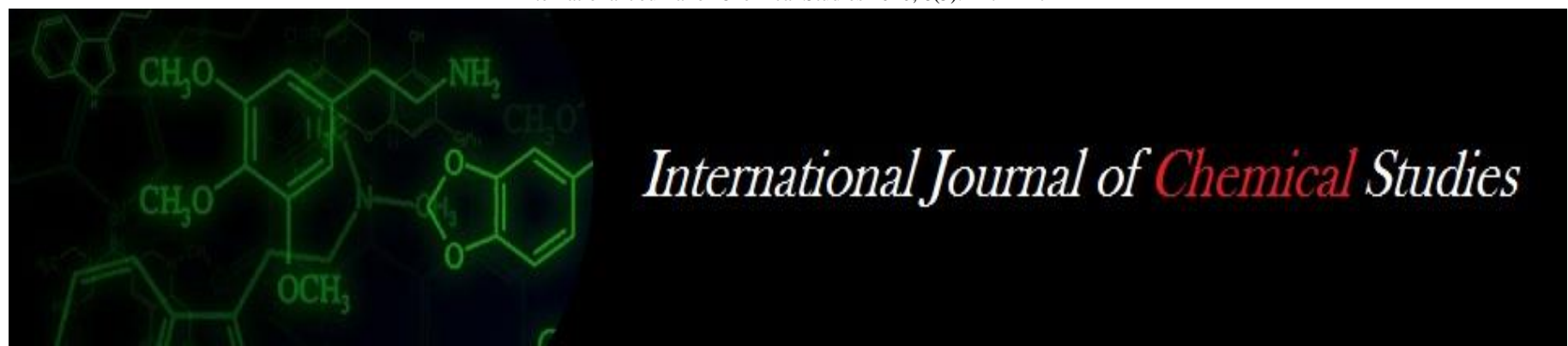

P-ISSN: 2349-8528

E-ISSN: 2321-4902

www.chemijournal.com

IJCS 2020; 8(5): 2272-2274

(C) 2020 IJCS

Received: 15-07-2020

Accepted: 21-08-2020

Ramprasad More

M.Sc. Dairy Science, College of

Agriculture, Parbhani

Maharashtra, India

Babasaheb Thombre

PhD. LPM, Associate Dean and Principal, College of Agriculture, Ambajogai VNMKV, Parbhani,

Maharashtra, India

Gajendra Londhe

PhD. Dairy Technology, Head

Department of AHDS, VNMKV,

Parbhani Maharashtra, India

Vijay Sawant

Department of Animal

Husbandry and Dairy Science,

College of Agriculture

VNMKV, Parbhani,

Maharashtra, India
Corresponding Author:

Ramprasad More

M.Sc. Dairy Science, College of

Agriculture, Parbhani

Maharashtra, India

\section{Studies on effect of addition of Bajra flour on chemical properties of Dahi}

\author{
Ramprasad More, Babasaheb Thombre, Gajendra Londhe and Vijay \\ Sawant
}

DOI: https://doi.org/10.22271/chemi.2020.v8.i5ae.10644

\begin{abstract}
In the present study dahi was prepared by replacing milk solids with biofortified bajra flour. Bajra flour of biofortified hybrid AHB-1200 was used which is rich in iron and zinc than local varieties/hybrids. Dahi was prepared from buffalo milk by blending with bajra flour at 2 per cent, 4 per cent, 6 per cent and 8 per cent. The requisite samples of $d a h i$ with different treatments were subjected for proximate analysis viz. Acidity, $\mathrm{pH}$, fat, protein, total sugar, moisture, total solid and ash. It was observed that as the blending of bajra flour decreased there was increase in protein, carbohydrate, total solids, ash, iron and zinc whereas, decrease in moisture content of dahi.
\end{abstract}

Keywords: Dahi, chemical, buffalo milk, Bajra

\section{Introduction}

Fermented dairy foods have been an important part of human diet in many regions of the world since times immemorial. Evidences showing the use of fermented milks have been found in archeological research associated with the Sumerians and Babylonians of Mesopotamia, the Pharoes of Northeast Africa, and Indo-Aryans of the Indian subcontinent Chandan, 2002 ${ }^{[5]}$; Fermented milk also plays an important part in the issue of lactose intolerance. Such people who are intolerant to lactose may ingest fermented dairy foods, because they would have little or no lactose. With regard to the therapeutic value of fermented milk, lactic acid bacteria produce acids such as lactic acids and acetic acid that inhibit the growth of many bacteria, especially gram negative and bacteria's which are pathogenic (Sharma, 1981) ${ }^{[11]}$.

Dahi is one of the oldest fermented milk products and is the most popular one in the Indian subcontinent. This product is known by different names in different countries of the world. According to PFA (1976), dahi or curd is the product obtained from pasteurized or boiled milk by souring, natural or otherwise, by lactic acid or other bacterial culture. It is an important fermented dairy product which is used as a base to make other dairy products like lassi and shrikhand. Dahi is a rich source of protein, calcium, riboflavin, vitamin B6 and vitamin B12 and others. It is reported to have better nutritive value than milk. Lactose-intolerant persons can digest $d a h i$, since the lactose present in milk had got converted to lactic acid by bacterial fermentation. (Wikipedia, 2012) ${ }^{[16]}$. As reported by Surra (2012) ${ }^{[13]}$, dahi contains good bacteria which help in digestion process. This beneficial bacterium helps to prevent probable cancer and other forms of stomach disorder. It reduces cholesterol level and prevents heart attacks. Curd is a probiotic food whose daily intake brings about the health benefits. The protein in curd is easily digestible in comparison to that found in milk. It is found that a majority of curd is digested for the same time that a quarter of the same quantity of milk is digested. According to the research conducted, eating curd regularly can improve and strengthen one's deficiency of phosphorus as it is good for people suffering from or at risk of osteoporosis.(Verma et al., 2011) ${ }^{[15]}$. Pearl millet (Pennisetum glaucum), also known as Bajra, is one of the four most important cereals (rice, maize, sorghum and millets) mostly grown in marginal agricultural zones with inconstant, unpredictable, receives very low annual precipitation $(200-500 \mathrm{~mm})$ and a day temperature is above $30^{\circ} \mathrm{C}$. (FAO, 2012). 
Pearl millet is recognized as an important crop in developing countries to overcome with food shortages and meeting the nutritional demands of a rising population. It is an essential source of dietary calories and protein for a wide segment of the poor population in their daily diet (Simwemba et al. 1984) ${ }^{[12]}$. Bajra grains are also a rich depository of the fat-soluble retinol (vitamin A) and tocopherol (23 mg/100 g). Pearl millet grains contain $0.38 \mathrm{mg}$ of thiamine, $0.21 \mathrm{mg}$ riboflavin, and $2.8 \mathrm{mg}$ of niacin (Hulse et al.1980) ${ }^{[6]}$. Bajra grains contain minerals like iron, phosphorus, magnesium, and calcium in containing appreciable amounts (Burton et al. 1992) ${ }^{[4]}$.

Micronutrient malnutrition, particularly vitamin A, iron and zinc-related malnutrition, has recently reported to be a most prevalent food-related health problem globally, particularly with people in those parts of the developing countries which have little access to vegetables, fruits and animal products in their meal intakes (Mason and Garcia 1993) ${ }^{[10]}$. Since the biofortification approach provides a sustainable and costeffective solution to this problem (Bouis, 2000) ${ }^{[3]}$. The fortification of milk and dairy products with iron and zinc is considered a possible solution to avoid iron and zinc deficiency diseases. Hybrid variety AHB 1200 variety of bajra contains 88 ppm iron while others contain average 40 ppm of iron it also contains $43 \mathrm{ppm}$ zinc. As milk is deficient in Iron, it was decided to add flour of AHB 1200 biofortified bajra during dahi preparation. Use of bajra flour in preparation of cereal based traditional dairy products like dahi would not only improve the product quality but also provide essential mineral like iron and zinc.

\section{Experimental Methodology Preparation of $\mathrm{dahi}$ -}

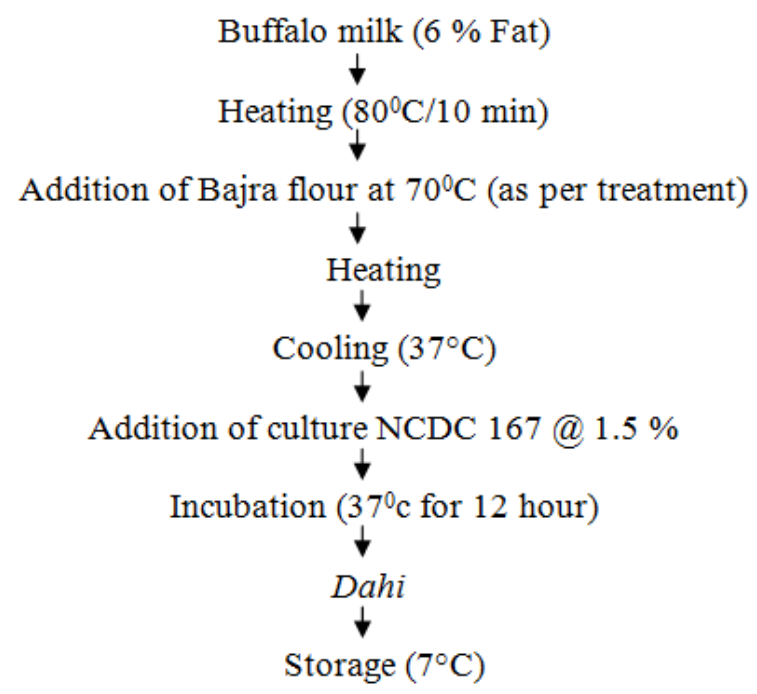

Flow chart for preparation of dahi lassi

During this study flour of iron rich variety of bajra (AHB 1200) and buffalo milk from buffalo unit Dept of AHDS will be utilized for preparation of dahi independently. Milk was Standardize to 6 per cent fat by using Pearson's square formula. The treatment details will be as below

\section{Treatment combinations}

$\mathrm{T}_{1}-100$ Parts of milk

$\mathrm{T}_{2}-98.00$ Parts of milk +2 Parts of Bajra flour

$\mathrm{T}_{3}-96.00$ Parts of milk +4 Parts of Bajra flour

$\mathrm{T}_{4}-94.00$ Parts of milk +6 Parts of Bajra flour

$\mathrm{T}_{5}-92.00$ Parts of milk +8 Parts of Bajra flour

\section{Preparation of Dahi}

First the composite buffalo milk was filtered and standardized to 6 per cent fat. It was pasteurized at $80{ }^{\circ} \mathrm{C}$ for 10 minutes. Bajra flour was added slowly during heating at $70^{\circ} \mathrm{C}$. Milk was cooled down to room temperature. Active dahi starter culture (ncdc-167) was inoculated under aseptic conditions at the rate of 1.5 per cent and mixed thoroughly. The inoculated milk was incubated at $37{ }^{\circ} \mathrm{C}$ temperature for $12 \mathrm{hrs}$ and dahi was obtained.

\section{Physico-chemical analysis of Dahi}

\section{A) Determination of fat}

Determined as per method described in AOAC (1990) ${ }^{[2]}$

\section{B) Determination of protein}

Determined by Kjheldhal method given in A.O.A.C (1965)

C) Determination of moisture, total solids, ash

Determined by method as described in IS: SP ( part XI ) 1981.

\section{D) Determination of carbohydrate}

Determined by substraction method.

\section{E) Determination of Iron and zinc}

Iron and zinc was determined by using atomic absorption spectroscopy (AAS) as given by Harjit Kaur and Karan Singh (2009).

\section{F) Statistical analysis}

The data were analyzed statistically by using Completely Randomized Design (CRD) as per Panse and Sukhatme (1985).

\section{Result and Discussion Chemical composition of $d a h i$}

The perusal of table 4.11 shows that the average fat, protein, carbohydrate, ash, total solids, moisture, iron and zinc contents of dahi.

Table 1: Gross chemical composition of dahi

\begin{tabular}{|c|c|c|c|c|c|c|c|c|}
\hline Treatment & Fat (\%) & Protein (\%) & Carbohytdate (\%) & Ash (\%) & Total Solid (\%) & Moisture (\%) & Iron (ppm) & Zinc (ppm) \\
\hline $\mathrm{T}_{1}$ & $6.00^{\mathrm{a}}$ & $3.89^{\mathrm{e}}$ & $5.16^{\mathrm{a}}$ & $0.80^{\mathrm{e}}$ & $15.85^{\mathrm{a}}$ & $84.15^{\mathrm{a}}$ & $2.00^{\mathrm{a}}$ & $3.99^{\mathrm{a}}$ \\
\hline $\mathrm{T}_{2}$ & $5.81^{\mathrm{b}}$ & $4.03^{\mathrm{d}}$ & $6.35^{\mathrm{b}}$ & $0.82^{\mathrm{d}}$ & $17.02^{\mathrm{b}}$ & $82.98^{\mathrm{b}}$ & $3.72^{\mathrm{b}}$ & $4.78^{\mathrm{b}}$ \\
\hline $\mathrm{T}_{3}$ & $5.75^{\mathrm{c}}$ & $4.11^{\mathrm{c}}$ & $7.48^{\mathrm{c}}$ & $0.84^{\mathrm{c}}$ & $18.18^{\mathrm{c}}$ & $81.82^{\mathrm{c}}$ & $5.44^{\mathrm{c}}$ & $5.56^{\mathrm{c}}$ \\
\hline $\mathrm{T}_{4}$ & $5.64^{\mathrm{d}}$ & $4.34^{\mathrm{b}}$ & $8.82^{\mathrm{d}}$ & $0.87^{\mathrm{b}}$ & $19.67^{\mathrm{d}}$ & $80.33^{\mathrm{d}}$ & $7.16^{\mathrm{d}}$ & $6.34^{\mathrm{d}}$ \\
\hline $\mathrm{T}_{5}$ & $5.50^{\mathrm{e}}$ & $4.42^{\mathrm{a}}$ & $10.01^{\mathrm{e}}$ & $0.91^{\mathrm{a}}$ & $20.84^{\mathrm{e}}$ & $79.16^{\mathrm{e}}$ & $8.87^{\mathrm{e}}$ & $7.12^{\mathrm{e}}$ \\
\hline $\mathrm{SE} \pm$ & 0.008 & 0.011 & 0.017 & 0.007 & 0.01 & 0.010 & 0.009 & 0.011 \\
\hline C.D at5\% & 0.025 & 0.033 & 0.052 & 0.022 & 0.03 & 0.033 & 0.02 & 0.036 \\
\hline
\end{tabular}

The values with different superscript row wise differ significantly at 5 per cent level of significance. 


\section{Fat content of dahi}

It is noticed from table 1 that mean fat content of dahi decreased slightly from 6.0 to 5.50 per cent. Fat content of dahi for treatment $\mathrm{T}_{1}, \mathrm{~T}_{2}, \mathrm{~T}_{3}, \mathrm{~T}_{4}$ and $\mathrm{T}_{5}$ was $6.00,5.81,5.75$, 5.64 and 5.50 per cent, respectively. Highest fat content was observed for control sample (6.0 per cent) and lowest in treatment $\mathrm{T}_{5}$ (5.50 per cent) which is incorporated with 8 parts of bajra flour. It might be due to lower fat content of bajra flour than buffalo milk used for preparation of dahi. Similar decreasing trend was observed by Ghule et al. (2015).

\section{Protein content of $d a h i$}

Protein content of dahi increased from 3.89 to 4.42 per cent. The mean protein content in dahi was $3.89,4.03,4.11,4.34$ and 4.42 per cent for treatment $T_{1}, T_{2}, T_{3}, T_{4}$ and $T_{5}$ respectively. The highest protein (4.42 per cent) was observed in $\mathrm{T}_{5}$ ( 8 parts of bajra flour) while lowest (3.89 per cent) was observed in $\mathrm{T}_{1}$ (control sample). It might be due to higher protein content of bajra flour. Results obtained were comparable with findings of Syama, (2014)

\section{Carbohydrate content of $\mathrm{dahi}$}

Carbohydrate content of dahi ranged from 5.16 to 10.01 per cent. The mean carbohydrate content in dahi was 5.16, 6.35, $7.48,8.82$ and 10.01 per cent for treatment $\mathrm{T}_{1}, \mathrm{~T}_{2}, \mathrm{~T}_{3}, \mathrm{~T}_{4}$ and $\mathrm{T}_{5}$ respectively. The lowest carbohydrate $(5.16)$ was observed in $\mathrm{T}_{0}$ while, highest (10.01per cent) was observed in $T_{5}$. Similar increasing trend was observed by Kumar and Das (2015) ${ }^{[9]}$.

\section{Ash content of dahi}

Ash content of dahi increased to some extent from 0.80 to 0.91 per cent. The mean ash content in dahi was $0.80,0.82$, $0.84,0.87$ and 0.91 per cent for treatment $\mathrm{T}_{1}, \mathrm{~T}_{2}, \mathrm{~T}_{3} \mathrm{~T}_{4}$ and $\mathrm{T}_{5}$ respectively. The lowest ash content was observed in $\mathrm{T}_{1}$ while highest ash content was observed in $\mathrm{T}_{5}$ results obtained were with findings of Kiruthika et al. (2018).

\section{Total solid content of $d a h i$}

The total solid content of dahi ranged in between 15.85 to 20.84 per cent. The mean total solid content in dahi was $15.85,17.02,18.18,19.67$ and 20.84 per cent for treatment $\mathrm{T}_{1}, \mathrm{~T}_{2}, \mathrm{~T}_{3}, \mathrm{~T}_{4}$ and $\mathrm{T}_{5}$ respectively. Lowest total solid content (15.85 per cent) was observed in $\mathrm{T}_{0}$ while the highest total solid content (20.84) was found for $\mathrm{T}_{5}$. Similar increasing trend in total solids due addition of cereal flour was similar results were obtained by Jain (2009).

\section{Moisture content of dahi}

Moisture content of dahi decreased from 84.15 to 79.16 per cent. The mean moisture content in dahi was 84.15, 82.98, $81.82,80.33$ and 79.16 per cent for treatment $\mathrm{T}_{1}, \mathrm{~T}_{2}, \mathrm{~T}_{3}, \mathrm{~T}_{4}$ and $\mathrm{T}_{5}$ respectively. Highest moisture content (84.15per cent) was observed in $T_{1}$ (100 parts of milk), while the lowest moisture content of (79.16per cent) was found for $\mathrm{T}_{5}$ (8 parts of bajra flour).

\section{Iron content of dahi}

Iron content of dahi increased from 2.00 to $8.87 \mathrm{ppm}$. The mean iron content in dahi was 2.00, 3.72, 5.44, 7.16 and 8.87 ppm for treatment $T_{1}, T_{2}, T_{3}, T_{4}$ and $T_{5}$ respectively. The highest iron content was observed in $\mathrm{T}_{5}$ while lowest was observed in $\mathrm{T}_{1}$, results were comparable with findings of Vilhekar (2014). It might be due to use of iron and zinc biofortified flour for blending.

\section{Zinc content in $d a h i$}

Mean zinc content in dahi was 3.99, 4.78, 5.56, 6.34 and 7.12 ppm for treatment $\mathrm{T}_{1}, \mathrm{~T}_{2}, \mathrm{~T}_{3}, \mathrm{~T}_{4}$ and $\mathrm{T}_{5}$ respectively. Zinc content of dahi increased from 3.99 to $7.12 \mathrm{ppm}$. The lowest zinc content (3.99) was observed in $\mathrm{T}_{1}$ (control sample) while highest $(7.12 \mathrm{ppm})$ was observed in $\mathrm{T}_{5}$. It might be due to higher zinc content of bajra flour used for blending. Similar results were observed by Basu and Tomar (2016).

\section{Conclusion}

It is concluded from present investigation it is concluded that due to addition of bajra flour there was increase in total solids, protein, carbohydrate, titratable acidity and ash content but decrease in fat and moisture content. Results also showed that with an increase in the bajra flour level, there was significant increase iron and zinc content of developed dahi.

\section{References}

1. AOAC. Official method of analysis, $11^{\text {th }}$ Edn. Assoc. Official Analytical Chemists, Washington, D. C, 1965, 4.

2. AOAC. Official Method of Analysis, Trends Food Science Technology. Association of Official Analytical Chemists, Washington, D.C. USA, 1990.

3. Bouis HE. Enrichment of Food Staples through Plant Breeding: A New Strategy for Fighting Micronutrient Malnutrition. Nutrition. 2000; 16:701-704.

4. Burton GW, Wallace AT, Rachie KO. Chemical Composition and Nutritive Value of Pearl Millet (Pennisetum Typhoides) Grain. Crop Science. 1992; 12:187-188.

5. Chandan RC, Shahani KM. Fermented Dairy Products in Biotechnology, 2nd ed. ED.G. Reed and T.W. Nagowithana, VCH Publishers, Germany. 1995; 10(9):386-418.

6. Hulse JH, Laing EM, Pearson OE. Sorghum and the Millets: Their Composition and Nutritive Value, Academic Press, New York, 1980, 187-193.

7. IS: 1479 Part-I Methods of test for dairy industry: Chemical analysis of milk.Indian Standards Institution, Manak Bhavan, New Delhi, India, 1960.

8. IS: SP: (Part XI). Methods of Test for Dairy Industry. Rapid Examination of Milk. Indian Standard Institution, Manak Bhavan, New Deihi, 1981.

9. Kumar A, Das A. Quality Evaluation of Sorghum Based Fermented Milk Beverage. The Pharma Innovation. 4(6, Part B), 2015, 83-85.

10. Mason JB, Garcia M. Micronutrient Deficiency-The Global Situation. SCN News. 1993; 9:11-6.

11. Sharma RK. Importance of Fermented Milk in Human Nutrition, Dairy Guide. 1981; 3(6):25-26.

12. Simwemba CG, Hoseney RC, Varrino-Marston E, Zelezak K. Certain B Vitamin and Phytic Acid Contents of Pearl Millet(Penniesetum Americanum). Journal of Agricultural and Food Chemistry. 1984; 32(1):31-34.

13. Surra Curds the therapeutic, 2012.: A must Have, URL http://surra.hubpages.com/hub/Curds-The-TherapeuticA-Must-Have,last updated: April19,2012

14. Panse YP, Sukatme PV. Statistical Methods for Agricultural Workers, $2^{\text {nd }}$ edn. Indian Council of Agricultural Research, New Delhi, 1967.

15. Verma SK, Singh Avinash. Therapeutic Effect of Dairy Product. Indian Dairyman.2012; 64(7):52-57.

16. Wikipedia, 2012.URL:Www.wikipedia.org 